\title{
Adoption of Local Values for Bureaucratic Reform in Lampung Province
}

\author{
1 YULIANTO, 2 NANA MULYANA, 3 SIMON SUMANJOYO HUTAGALUNG \\ 1,2,3 Jurusan Administrasi Negara FISIP Universitas Lampung, Jl.Sumantri Brojonegoro No.1 Rajabasa \\ email: ${ }^{1}$ yulianto@fisip.unila.ac.id, 2nana.mulyana@fisip.unila.ac.id, 3simon.sumanjoyo@fisip.unila.ac.id
}

\begin{abstract}
Bureaucratic reform is not only dealing with structural aspects but also cultures that are difficult to change. However, it can be done by adopting the values embedded in the cultural identity of the community. This study aims to identify the local values that can be adopted to reform the bureaucracy in Lampung Province and develop those model values. Qualitative approaches are used with data collection techniques of interviews, documentation, and focus group discussions. The research location is in Lampung Province and involves research informants consist of traditional and bureaucratic leaders. Data analysis techniques used is interactive data analysis model. The research results identify 4 (four) local values, namely Piil Pesengiri (Principle of Success), Nemu Nyimah (Principle of Choice), Nengah Nyappur (Principle of Equality) and Sakai Sambayan (Principles of Cooperation). The adoption model of local values can be developed through a conciliation approach strategy. This approach is chosen because it provides guidance to change bureaucratic culture into a better effectiveness and could minimize the conflicts that may happen.
\end{abstract}

Keywords: Bureaucratic Reform, Local Values, Local Wisdom

\section{Introduction}

In governance, the role of bureaucracy has a significant position and function. A bureaucrat is a deciding factor in addition to the systems and policies that have been published. Many aspects of the downturn bureaucracy in Indonesia are all come down to the behavior of the bureaucratic apparatus. Bureaucratic apparatus behavior that was largely untouched by the policies of structural reform during changes in the body that make us experience sluggish bureaucracy. Transparency and accountability are the main problems, evident from the study of Hyden, Court and Mease (2003) who made indicators which proved the correlation with performance. The ideas of change were adopted from the universal concept which becomes a routine aspect of the program but does not touch the bureaucratic culture that has been attached tightly. Bureaucracies also tend to be associated with hierarchical and even authoritarian forms of governing, even though at least part of the logic for institutionalizing the bureaucratic form of governing was to ensure equal treatment of citizens and provide clients with records and justifications for the decisions being made about them within the public sector (Peters, 2010).

A government bureaucracy is formed by the cultural and historical context (Im, 2014). Thus the reform of the bureaucracy, actually, has a very close relationship with the question of culture. Commonly, there are two ways of thinking about the relationship between the two aspects. First, revamping dimensions of culture or cultural reform should be taken to accelerate the process of bureaucratic reform. Second, the reforms that carried out consistently will give birth to new cultural values which are much better than the previous ones. The first mindset looked at the cultural factors as a precondition for reformation, while the second half saw the cultural mindset as a result of indirect (by product) of a series of the reform process. Between both mindsets, there is a hidden message which tells that culture is an inseparable component of the reform program, and cultural factors should not serve as an excuse for not reforming. As James $Q$.

Received: August 17, 2017, Revision: April 06, 2018, Accepted: June 04, 2018

Print ISSN: 0215-8175; Online ISSN: 2303-2499. DOI: http://dx.doi.org/10.29313/mimbar.v34i1.2854.24-32

Accredited B based on the decree No.040/P/2014, valid on February, 18, 2014 until February, 18, 2019. Indexed by DOAJ, Sinta, IPI 
Wilson has commented, the way in which a bureaucracy operates cannot be explained simply by knowing its tasks and the economic and political incentives it confronts. Culture makes a difference (Dilulio,2011).

The importance of these relationships, among others, highlighted by the Former Vice Minister of Administrative Reform and Bureaucratic Reform, Eko Prasojo, at the opening of an international seminar with the theme of Accelerating Reform Based Local Wisdom and Culture of Excellence in Denpasar, February 20, 2014 he expressed that value superior culture and local wisdom in some area proved to be able to encourage the growth of democracy, and it can be used to speed up bureaucratic reform (Prasojo, 2014). Local government of Denpasar city carries the motto of "Sewaka dharma" which contains the value of the principle of serving as an obligation (Zulaiha, Ariati, \& Muhardiansyah, 2008). This value is very good to be applied in public service.

Local wisdom reflects the identity/ local personality that caused its members to be able to actualize their potentials to survive (Bakti, Hafiar \& Budiana, 2017). Meanwhile, according to Moendardjito (Ayatrohaedi,1986), the element of local culture has the potential to be a local genius because it has proved to survive up until now. The characteristics of such values are: (1) able to withstand the external culture; (2) It has the ability to accommodate external cultural elements; (3) Have the ability to integrate external cultural elements into indigenous culture; (4) Have the ability to control; (5) Able to provide direction to the culture development. This opinion would be more convincing if local wisdom has a very strong value structure and able to live along with the social development of society. In long term, local genius is an important element in the process of manufacturing and implementation of government policy (Irmayani, Nurbani, \& Bangun, 2015).

Local wisdom from many local cultural values can become an inspiration and principles value of behavior in government bureaucracy. Cablaka in Banyumas, for example, is an inspirational values of honesty, decisiveness, patriotism, simplicity and empathy (Priyadi, 2007). In addition, there is also a philosophy of Dalian Na Tolu in North Sumatra that guides the bureaucratic leadership to provide services to the community (Simanjuntak,2012). Several other areas have also been applying local wisdom in the reform of bureaucracy, among others, East Java, West Sumatra, South Sulawesi, and others. These local values are critical to the successful efforts of innovation in local governments (Hutagalung \& Ruari, 2017).

A bureaucratic culture that develops in a particular area cannot be separated from its surrounding culture and social Environment (Khatib,1996). The social environment has a system of norms, value systems, belief systems, customs, even a view of life that has been understood by the members of the community as something that is good and true (Leavit, 2002). The system of norms and values is recognized as a guide or reference in the act and behavior of the people (Gilman, 2005).

Therefore, the reform of the bureaucracy which has been developed in a structural approach is also important to pay attention to the cultural aspects of the structural changes that can be attached to an institutional bureaucracy of local government. Priorities that need to be developed are potentials adoption and development of a culture of excellence at the local level to support the acceleration of bureaucratic reforms (Burrett, 2016). This is an attempt to support the reform spirit of the culture that has been very difficult to change to a better direction (Greener, et al., 2014). Changes in bureaucratic culture will form relationships that influence the culture lives in society. In that position, the culture lives in society in the form of local wisdom can also encourage more effective bureaucracy reform. It is time for us to not only see the good bureaucratic practices of those western countries, but begin to see the power we have already had (Effendi, 2015). Based on that, this paper will study the identified potentials of local knowledge to support the implementation of bureaucratic reforms.

\section{Research Method}

This research is conducted in the form of longitudinal study which tries to analyze and focus on a research location in long period. Stages in this research are to identifying potential local values, then designing the adoption model of local values, and analyzing the appropriate strategies for the implementation. Using qualitative research, data collecting was implemented in three ways; a literature study which includes 
reference materials indigenous to the area of research, field documentation interviews with informants, and focuses group discussions. It also uses secondary data and information collection which relevant to be utilized in this study, including the identification of bureaucratic reform model in accordance with existing conditions, as well as getting through an analysis of some models of best practices that have been formulated, developed or applied to other areas in Indonesia. The research location is in Lampung Province and purposively involves the research informants consist of traditional leaders representing ethnic diversity in Lampung Province, namely Pesisir and Pepadun and also bureaucracy leader representing Lampung government. The analysis used in this study is interactive model of analysis by Miles and Huberman (1992) with the working procedure of data reduction, data presentation, data verification, and drawing conclusions. In order to maintain the quality of data applied, this research also uses the triangulation techniques.

\section{Identification of Local Values for Bureaucracy Cultural Reform}

The results of data analysis have found the same pattern that the most important local values in the society of Lampung are Piil Pesenggiri, Nemui Nyimah, Nengah Nyapur and Sakai Sambayan. Piil Pesenggiri can be defined as a concept of self-esteem, shame feeling over bad things, and high-minded. In general (ordinary people's understanding), Piil is always interpreted as the dignity of the specific situations or circumstances in a social relationship among people in a particular neighborhood or community. Piil Pesenggiri has a position as cultural capital and strategy of Lampung people (Irianto \& Margareta, 2011). Fachruddin and Haryadi (1996) explain that Lampung value's culture of life philosophy that can support Pancasila is known as Piil Pesenggiri philosophy.

Nemui Nyimah principle is categorized into five indicators: manners in the services, indicators of good conduct in the service, indicators of knowledge in providing services which means that officers understand their duties or able to determine the duties they should carry, the indicator skill in serving, and the indicators of officers' serving accountability (Syani, 1996). Personally, this principle shows politeness and morality, containing the notion of receiving all guests with a sweet face and open hands (Siswanto,

\section{Riyanto \& Bestari, 2014)}

Nengah Nyappur principle of can be categorized into five indicators: first, social and friendly indicator in serving; second, indicator of tolerance or tolerance in serving which suit the conditions of time and usually associated with employees' hospitality; third indicator of Nengah Nyappur principle is to uphold the high principles (obey the rules, do the duties, would not be bribed, etc.); fourth indicator of Nengah Nyappur principle is the ability of good communication among officer at higher level; fifth indicator is the ability of officers to compete in providing the best service to the community (Syani, 1996). The reason is that there is no sense of competence or competition to provide the best service in government, for example, rapid, service right on time, and not wasting time talking no sense when do the serving. This principle is even put forward as an important social capital in the development of government programs (Mardihartono, 2011).

Sakai Sambayan principle can be arranged into four indicator value: first; convenience of service; second, the attitude of responsiveness; third, communication and coordination which means the ability to cooperate with other employees in serving the users; fourth, an attitude that can be trusted to serve the public (Syani,1997). The principle of Sakai Sambayan, in essence, is showing a deep sense of participation and high solidarity with the community towards something or an activity or obligation that should be done (Pairulsyah, 2013).

Piil Pesenggiri principle is one of the principles contained in Lampung cultures which can be defined as Lampung people's philosophy of life. Piil Pesenggiri principle inherent in a person that can be seen from how a person has a sense of self-esteem, has a customary title as an achievement, polite, glad to get along with others, and has a willingness to cooperate with others (Syani,1997). Based on data analysis, it is known that the Piil Pesenggiri principle consisting of self-esteem, shyness and magnanimous, and rated as a very important thing and became the first priority. Piil means behavior, and Pesenggiri means high moral, big soul, knowing yourself, knowing the rights and obligations. Piil Pesenggiri is a potential of local social culture that has the function as a source of motivation so that everyone can be a dynamic in an effort to fight for positive values, honorable life, and being appreciated 
in community's life. As a consequence of struggling and maintaining honor in social life, people of Lampung are obliged to control their behaviors and keep their good names to avoid the low attitude and actions that are not commendable.

Nemui Nyimah principle is important to be possessed by every bureaucrat, as resource study assessed it as important value as well. Principle of Nemui Nyimah in the context of public service is the nature of social concern. This is based on the sense of sincerity from the bottom of the heart to create harmony of family life and society. Thus, the cultural element of Nemui Nyimah can be interpreted as a good attitude and illicit acts that are not in accordance with prevailing social life norms. The concrete form of Nemui Nyimah in the context of people's life today is more accurately translated as a social attitude and being open to the guests or other persons. A family that has a concern for human values, of course, is widely looking forward to get the motivation to work hard, being honest, and not do things that would harm others.

Then, the principle of Nengah Nyappur which includes the sincere willingness to listen to other people's opinion becomes the next priority, followed by the principle of Sakai Sambayan.. Nengah-Nyappur illustrates that members of the Lampung community prioritize a sense of kinship and become sociable and friendly with everyone, as well as not to discriminate other tribes/ races, religion, level, origin and class. A social and friendly attitude fosters a passion for cooperation and a high tolerance among people. Tolerance will cultivate a curiosity, listen to the advice of others, spur the spirit of creativity, and responsive to the development of social symptoms. Therefore, it is possible to conclude that the attitude of Nengah Nnyappur points out to the value of deliberation for consensus. The attitude of Nengah Nyappur symbolizes the good, orderly, and attitude of the mind as the embryo of sincerity to increase knowledge and adaptive attitude toward change.

Principle of Sakai Sambayan means to show a sense of participation and solidarity in the community for activities or obligations that must be done. People of Lampung community equipped with a sense of family and accompanied with an attitude of hanging out and make friends with anyone without distinguishing religion and class levels. This attitude of hanging out and make friends and principle of Sakai Sambayan, in essence, show a sense of participation and solidarity in society. Lampung society will feel less respectable if they are not able to participate in a community's activity. This behavior describes the attitude of mutual tolerance, so that a person will voluntarily give anything if it has a benefit value for the person or another member of the community in need. Sakai Sembayan always maintains an attitude of togetherness, including the mutual help, especially towards the weak in the overall sense, both inward and outward. In brief, the description can be simplified into the figure 1.

From figure 1 , we can observe

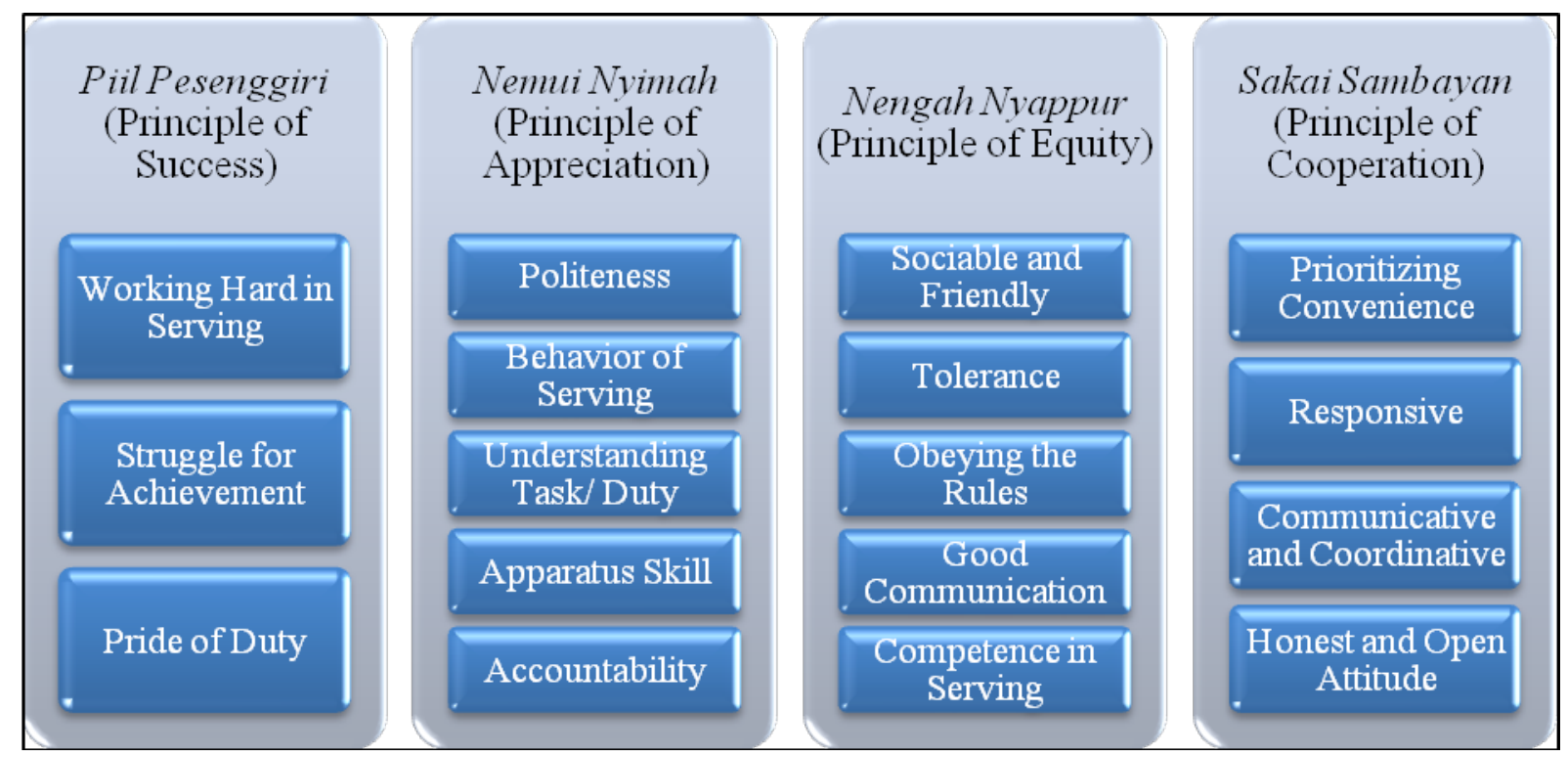

Figure 1. Identification of Bureaucracy Values Adopted From Lampung Cultural Values 
categorization of performance values that have in common with the essence of each cultural value of Lampung people. The principle of Bejuluk Beadek is related to the value of hard work, performance-oriented and pride in work, while the Principle of Nemui Nyimah is related to the value of politeness, service, high performance, and accountability. Nengah Nyapur principle is associated more on the value of equality and communication, while the principle of Sakai Sambayan include responsive, honest, and open. All of these values are relevance as well as aspects of performance appraisers of bureaucratic organizations that have been known by the apparatus. The suitability makes adoption of local cultural values is expected to face no resistance or obstacles.

\section{Bureaucratic Culture Reform Strategy Based on Local Values}

A crucial aspect to be considered in the culture reform implementation is a strategy to introduce and adopt local values. This should be taken into account appropriately and clearly. A research by Sofyan (2006) states that cultural values which misunderstood and improperly practiced are detrimental to the effectiveness of an organization. His research on the Regional Employment Board (BKD) in North Lampung District shows there is a negative impact of Piil Pesenggiri principle which affects the organizational effectiveness. The Piil Pesenggiri influence was tested here through three factors in between variables, which are search and resource utilization, individual behavior, and organizational structure. The study recommended efforts to solve the problem by repositioning the ideal concept of Piil Pesenggiri, disseminate that ideal concept, and consistently strengthen social and formal controls on bureaucratic institutions.

Therefore, encouraging bureaucratic culture reform and changing the organizational culture which has so long became the basis of establishment and make a design of structural change is not an easy matter. It is required a particular form of approach and strategy in order to change the organization and cause less negative impact (Goebel, 2016). In the context of Piil Pesenggiri Lampung culture adoption, it can refer to the conception of Ian Brooks and Paul Bate (1994) on cultural change approach as follow: (a) aggressive approach: cultural change by using power approach, non-collaborative, create conflict, forced nature, win-lose system, unilateral, and use decree. According to Schein, it is called structural approach because it is uprooting the existing culture. In this approach, the adoption of tangible local value of Piil Pesenggiri is done with the support of local leaders, traditional leaders, and informal leaders of the community. It takes a series of actions to frontally eliminate cultural or old habits, even with the use of a set of regulations that restrictive or punitive. This approach will be effective if it is done through the organization structure of government and social structures that accompanied the mechanism of punishment and reward; (b) conciliative approach:cultural change is done collaboratively, solved the problem together, win-win solution, integrative and introducing a new culture first before replacing the old one. In this approach, the adoption of local values is done in a coordinated manner and compromised shared by all parties involved in the cultural change or habits within the bureaucracy. Compromise may become the priority choice to be the first value in the adoption and should not be changed. The introduction of a new culture as a result of adoption of local culture values seems to be more acceptable. It's just that there will be a compromise and a shared meaning about the practice/application of these values; (c) corrosive approach: cultural change that has to do with the informal approach, evolutionary, not premeditated, politically, coalitions and rely on networking, the old culture little by little destroyed and replaced with a new culture. In this approach, the adoption of a local value for bureaucratic reform carried out outside the structure and formal sets of rules. Efforts changes are made gradually without a gradual strategy and more likely to rely on the willingness to eventually change the culture and old habits into new ones and moving towards the better. However, it took longer time to achieve those changes; (d) indoctrination approach: normative approach using re-training and education programs to understand a new culture. In this approach, the change was made formally in a gradual pattern and has a clear strategy to achieve. Changes in culture and habits are done by conducting various activities that can provide insight into the changes and the attitude of the organizers of bureaucracy. Education and training are carried out repeatedly to all State Civil Administrative, either new or old ones. Conflict or ineffectiveness may occur if you choose to apply this approach without a clear strategy and consistency. However, with the 
cultural Lampung value as the basis of the change means the initial stages will be more easily to be accepted. Furthermore, based on the above approach, Brooks and Bate stated there are five stages of cultural change:

Deformative (phase of idea of change) is the cultural change that has not really happened and merely confirms the idea of why cultural change is necessary. At this stage, shock therapy usually occurs and exposure to dramatize the need for cultural change. This phase begins with the adoption of real cultural values identification that can be implemented into the design of regional policies, both regional head regulation and lower government regulation in form of ethics description and guidelines implementation. Ideas that have been identified in the process of adoption of the local cultural values will be set forth in legal writing and have the power to be obeyed. There will be some parties who will not agree or resistant to the idea, but a formal approach is made in protocol design that force the parties to comply the rules.

Reconciliation (phase of support the idea of change) is a phase where various parties are against or support the idea of cultural change. This is the stage of negotiations for both the initiator or the drivers of cultural change or the parties to either agree or disagree with the change. This phase begins with the dialogue between the parties that are resistant to the values of change and the parties that support it. Negotiations occur in the scope of priority value applied and technical aspects of new values implementation, so that it will eventually reach an agreement and weakens the opposition of those who are resistant or do not agree with the change.

Accu lturati ve (communication and commitment phase) is a phase of intensive communication to gain agreement following the previous stage process in order to strengthen the commitment. At this stage, it is necessary to perform the process of socialization and education to help penetrate and disseminate the cultural change. This stage is characterized by the intense attention from all stakeholders and the exchange of deeper understanding of the new values and the accompanying of technical aspects. Parties that are resistant and those who support the change values implementation Create a dealing outline which will be carried out jointly. In addition, this phase is also characterized by the effort or activity of socialization and training given to civilian state apparatus with the aim to get more formal cultural values establishment that has a high level of compliance.

Enactive (phase of implementation of change) is the implementation of thought, discussion, and debate outcomes about a new culture. There are two forms of personal enactment (each individual act which allows the culture to be part of their lives) and the coll e ctive en actment (the cultural actors act together to solve the cultural problem). This stage is characterized by drafting the regulations and guidelines or codes of ethics, and starting the implementation of socialization and training. The next part is the understanding and meaning of new culture for personal values of each civilian personnel and taking these new values into the spirit of local work as a great team. In the end, the whole civil state apparatus and local officers who make the change will generate new values as well as implications to cultural changes and new habits within the bureaucracy.

Formative (phase of structure formation and culture form) is currently shaping and designing the structure so that the culture that once invisible becomes visible to all members of the organization. This stage is characterized by the change value of almost all the civil state apparatus which leads to a bureaucratic culture and eventually creates a total change. The next stage results in culture and habits change which increasingly embedded and reflected into the activities and performance of government bureaucracy.

Based on data analysis and FGD results, it was agreed that in adopting local values model, local government bureaucracy reform chose conciliative approach as its implementation strategy. The approach was chosen because it provides change direction for better effect iveness (Cloutier, et al., 2015), as well as the patterns of formal legal with peaceful adoption to minimize conflicts that can frustrate change in culture and customs bureaucracy (Paffarini, 2016). In order to provide a greater degree of success then all stages of Bates cultural change can be applied (Goebel, 2016). When a set of values is aimed to reform the cultural bureaucracy, a model adoption of local values can be arranged and added to bureaucratic reform as shown by the figure 2 .

The model identifies key principles that can be operationalized in to organizational and employee performance. From that identification, an adoption mechanism and 


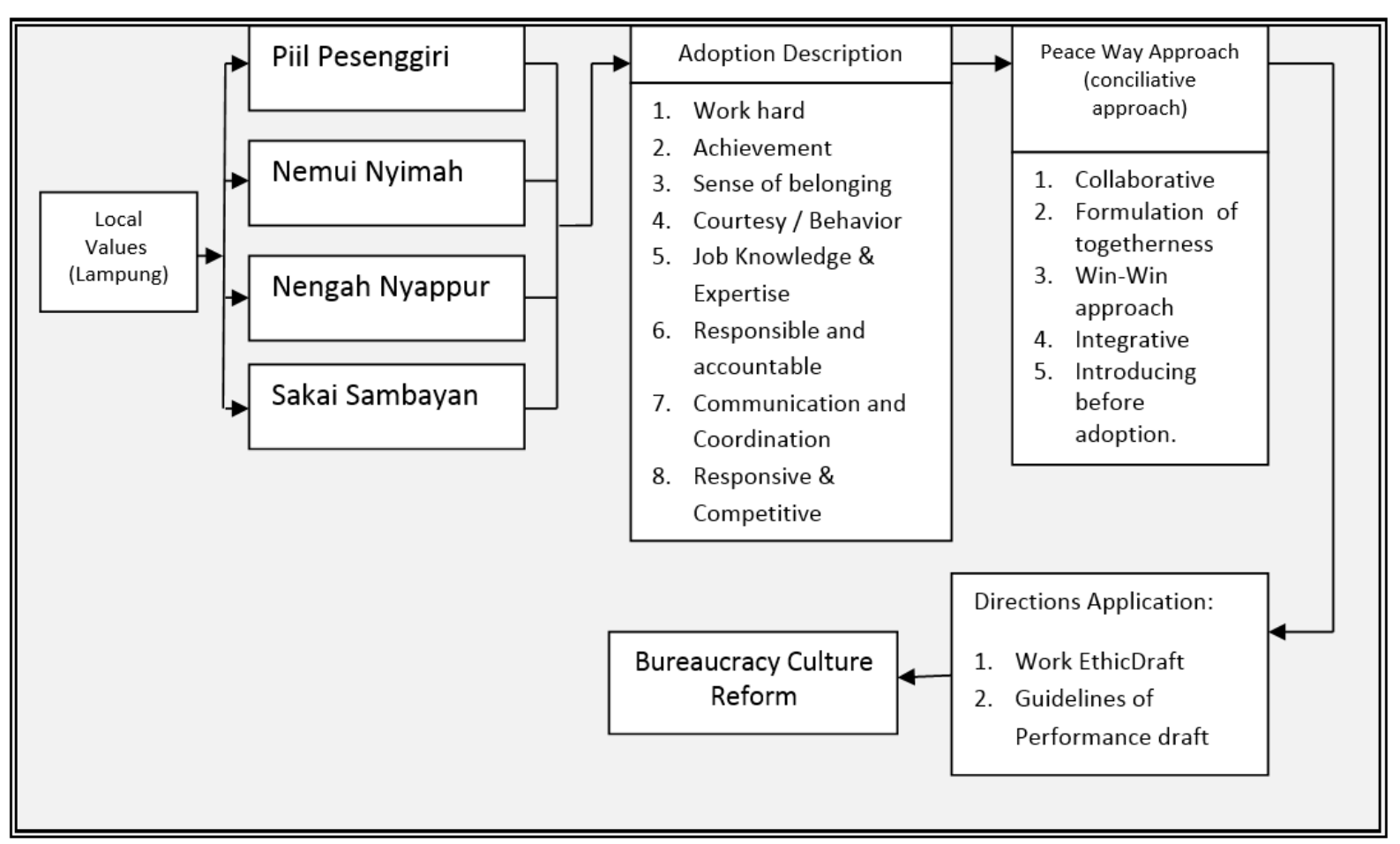

Figure 2. Adoption Model of Local Values in the Context of Bureaucracy Reforms in Lampung Province

application is made with peaceful approach to minimize the occurrence of potential conflict and facilitate the absorption of principles' values. The concrete nature of value creation design and adoption mechanism is directed into the form of work ethic and performance guidelines design. The work ethic draft basically regulates the personal and social aspects of employees in an organization. Adoption of this work ethic requires consistency and exemplary order to achieve optimal success. Whereas the draft performance guidelines can be integrated into reward and punishment mechanisms that apply to employees and organizations, so that the achievement of success will be more controllable. Nevertheless, the implementation of these performance guidelines requires clear consistency and control to safeguard the adoption of value principle desired.

In the process of cultural compromise, local wisdom serves not only as a filter when a clash occurs between local culture and the demands of change. Local wisdom with the resource of local cultural values plays a role as moral guidelines in problem solving when a culture confronts the antagonistic growth of life interests. As an example to the lives of local people, the process of cultural compromise always takes account of local cultural elements when face new cultures. The elements are considered, sorted, and selected to determine which are relevant and which are contradictory. The result always shows the face of elegant compromise where each element gets its place and emerges in new form as a harmonious unity.

Surely, the formation of this harmonious unity cannot be separated from the compromise of justice that touches the interests of various parties. These interests are very broad in scope, but the outline covers various issues related to human survival, especially the primary and practical. Policymakers must be able to sort out and choose a compromise process that benefits all parties, then addressing, organizing, following up the direction of change of interests to remain in the principle of tingling. Culture as a granary of local cultural values can be a guideline in an effort to reach a variety of interests that exist in harmony, without any party sacrificed.

\section{Conclusion}

There are several conclusions that resulted from this study: (1). Reform models can be constructed by adopting the principles of Lampung cultural values. Those 
principles are Piil Pesenggiri which consisting of self-esteem, shyness and magnanimous, considered as a thing that can be decomposed into several derivatives principles. The principle of Nemui Nyimah is important to be possessed by every bureaucrat where resource study assessed it as being important as well. Then, the principle of Nengah Nyappur which includes meaningful willing to listen to other people's opinion as the next priority, followed by the principle of Sakai Sambayan, as well as a variety of other responses that are able to describe. Nemui Nyimah principle in the context of public service is the nature of social concern, the principle of Sakai Sambayan which in essence shows a sense of participation and solidarity in the community to activities or obligations that must be done, Nengah Nyappur is a willingness to listen, reacts fast, and shows good responsiveness. (2). Adoption model of local values in the reform of local government bureaucracy used peaceful path selection approach (conciliative approach). The approach was chosen because it provides direction change for better effectiveness, as well as the patterns of formal legal that peacefully adopted to minimize conflicts that can frustrate change in culture and customs bureaucracy. In order to provide a greater degree of success then all stages of Brooks and Bates cultural change can be applied.

Based on the discussion and conclusion above, some recommendations can be produced as follow; (1). It needs a collective agreement made by the government, traditional leaders, community leaders and academics to oversee the implementation of further bureaucratic reform based on local values, as well as supervise and evaluate the performance of the application. (2). the need for a technical design that can be understood by the civilian apparatus of each country, in this case the form of guidance or guidelines that can be easily recognized and understandable.

\section{References}

Ayatrohaedi. (1986). Kepribadian Budaya Bangsa (the nations cultural personality). Pustaka Jaya. Jakarta

Bakti, I., Hafiar, H., \& Budiana, H. R. (2017). Environmental Communication Based on Local Wisdom in Anticipation of Citarum Flood. MIMBAR, 208-216.

Burrett, T. (2016). Explaining Japan's Revolving Door Premiership: Applying the Leadership Capital Index. Politics and Governance, 4(2), pp. 36-53.

Cloutier, C., Denis, J.-L., Langley, A. \& Lamothe, L. (2015). Agency at the Managerial Interface: Public Sector Reform as Institutional Work. Journal of Public Administration Research and Theory, 26(2), pp. 259-276.

Dilulio, John. (2011). Deregulating the Public Service: Can Government be Improved?, The Brooking Institute.

Effendi, N. (2015). Pengembangan Sumber Daya Manusia Berbasis Kompetensi di Kantor Pemerintah Kota Bandar Lampung. MIMBAR, 1-10.

Fachruddin, dan Haryadi. (1996). Falsafah Piil Pesenggiri Sebagai Norma Tatakrama Kehidupan Sosial Masyarakat Lampung. CV. Arian Jaya. Bandar Lampung.

Gilman,S. C. (2005). Ethics codes and codes of conduct as tools for promoting an ethical and professional public service: comparative successes and lessons. OECD.ORG, Washington DC.

Goebel, C., (2016). Taiwan's Fight Against Corruption. Journal of Democracy, 27(1), pp. 124-138.

Greener, I. et al. (2014). Reforming Healthcare: What's the Evidence? 1 ed. Birmingham: Policy Press.

Hutagalung, S. S., \& Ruari, I. (2017). Analisis Inovasi Pelayanan Publik (Study Implementasi Program Rumah Sakit Keliling Provinsi Lampung pada Daerah Operasional Kabupaten Pesisir Barat. SNAPP 2017 (pp. 215-226). Bandung: Unisba.

Hyden, Goran, Court, Julius and Mease, Ken. (2003). The Bureaucracy and Governance In 16 Developing Countries, World Governance Survey Discussion Paper 7, July 2003, Overseas Development Institute, https://www.odi.org/resources/ docs/4104.pdf.

Brooks, I., \& Bate, P. (1994). The problems of effecting change within the British civil service: a cultural perspective. British Journal of Management, 5(3), 177-190.

Im, Tobin (2014), Bureaucracy in Three Different Worlds: The Assumptions of Failed Public Sector Reforms in Korea, Public Organization Review, December 2014, Volume 14, Issue 4, pp 577-596. http://link.springer.com/article/10.1007/ s11115-013-0246-7.

Irianto, S., \& Margareta, R. (2011). Piil Pesenggiri: Modal Budaya dan Strategi Identitas Ulun Lampung. Makara Sosial Humaniora, 140-150. 
Irmayani, T., Nurbani, \& Bangun, S. (2015). Local Genius dan Implementasi Pengarusutamaan Gender pada Pemerintahan Kabupaten di Sumatera Utara. MIMBAR, 475-484.

Khatib, T. M. (1996). Organizational culture, subcultures, and organizational commitment. Retrospective Theses and Dissertations. 11540. https://lib.dr.iastate.edu/rtd/11540.

Leavitt, R. (2002). Developing cultural competence in a multicultural world: Part 1. PT Mag Phys Ther, 10, 36-48.

Mardihartono, A. (2011). Kebijakan Jejamo Ngebangun Sai Bumi Nengah Nyapur di Kabupaten Tulang Bawang Lampung. Jurnal Studi Pemerintahan, 1-22.

Miles, M. B., \& Huberman, A. M. (1992). Analisis data kualitatif. Jakarta. UI Press.

Paffarini, J. (2016). Justice reforms and migration of adr models through the "new" international conditionality. the cambodian arbitration council. Comparative Law Reform, 7(1), pp. 1-26.

Pairulsyah. (2013). Kualitas Pelayanan Publik SAMSAT Lampung Dalam Perspektif Budaya Lampung. Fiat Justisia Jurnal IImu Hukum , 168-180.

Peters, B.G. (2010). Bureaucracy and Democracy.Public Organization Review, September 2010, Volume 10, Issue 3, pp 209-222.

Prasojo, E. (2014, Mei 12). Kemenpan RI. Retrieved from Berita, http://www. menpan.go.id/berita-terkini/905percepat-reformasi-birokrasi-dengankearifan-lokal

Priyadi, S. (2007). Cablaka Sebagai Inti Model Karakter Manusia Banyumas. Jurnal Diksi,
14 (1), 11-18.

Simanjuntak, T.H. (2012). Kapasitas Institusi Pemerintah DKI Jakarta Dalam Pelayanan Catatan Sipil. Universitas Padjadjaran. Bandung.

Siswanto, E., Riyanto, A., \& Bestari, P. (2014). Pelestarian budaya piil pesengiri dalam masyarakat mulitikutural lampung serta pengaruh globalisasi ditinjau dari aspek kajian pendidikan kewarganegaraan. Civicus: Jurnal Pendidikan Kewarganegaraan, 140-160.

Sofyan, Riski. (2006). Culture Piil Pesenggiri and organizational effectiveness BKD: A case study in North Lampung regency. Thesis. Gadjah Mada University. Yogyakarta.

Syani, Abdul. (1996). Local Regional Cultural Identity Formation It means For Nations. The paper, presented in the Regional Cultural Extension Lampung forum within the framework of Creation and Development of Regional Kebudayan Lampung, in the Hall of Upgrading Teachers. Bandar Lampung. 1996.

Syani, Abdul. (1997). Role of Formal and Informal Leaders for Development of National Culture. Papers, Cultural Extension, in Hall Upgrading Teachers. Bandar Lampung.

Zulaiha, Aida Ratna; Ariati, Niken; Muhardiansyah, Doni. (2008), E-Sewaka Dharma, pelayanan publik berbasis teknologi informasi dan komunikasi di Kota Denpasar; Seni Untuk Melayani, Komisi Pemberantasan Korupsi (KPK). Direktorat Penelitian dan Pengembangan, ISBN: 9789791900911. 